\title{
Polychaete assemblages and sediment pollution in a harbour with two opposing entrances
}

Received: 26 November 2003 / Revised: 12 May 2004 / Accepted: 12 May 2004 / Published online: 15 July 2004

(C) Springer-Verlag and AWI 2004

\begin{abstract}
The harbour at Ceuta is one of the most important harbours in the Strait of Gibraltar. The sediments are moderately polluted with organic matter and heavy metals but the harbour has two opposing entrances and a connecting channel which increases water renewal and dissolved oxygen across the harbour. For these special conditions, the value of the soft bottom polychaete community as a bioindicator, and possible advantages of the presence of two harbour entrances on biotic assemblages, were studied. Twenty-one stations were selected, and 27 variables were measured in the sediment of each station. The polychaete species richness and Shannon diversity values were similar inside and outside the harbour. Nevertheless, the Pielou evenness index was significantly higher in the external stations due to high densities of some species of polychaetes such as Pseudomalacoceros tridentata and Capitella capitata inside the harbour. The multivariate approach based on polychaete species composition was much more sensitive than univariate analyses at discriminating between internal and external stations. The pollution gradient and granulometric parameters were the main factors affecting polychaete distribution. Polychaete species richness and diversity in sediments inside Ceuta harbour were higher than in conventional harbours due to the positive effects of increased water renewal. These results should be taken into consideration in design, construction and remodelling of future harbours.
\end{abstract}

Keywords Polychaetes $\cdot$ Harbour ecology $\cdot$ Sediment pollution $\cdot$ Ceuta $\cdot$ North Africa

Communicated by: H.-D. Franke

J. M. Guerra-García (屯) · J. C. García-Gómez

Laboratorio de Biología Marina,

Departamento de Fisiología y Zoología, Facultad de Biología, Universidad de Sevilla,

Avda Reina Mercedes 6, 41012 Seville, Spain

e-mail: jmguerra@us.es

Fax: +34-954-233480

\section{Introduction}

Harbours are among the most altered coastal areas. They usually represent polluted areas with low hydrodynamism, reduced oxygen in the water column, and high concentrations of pollutants in the sediment. Anthropogenic discharges into harbours and shallow bays, where residence times are extended due to partial enclosure, can have severe effects on local pelagic and benthic communities (Danulat et al. 2002). Ceuta harbour is one of the most important harbours in the Strait of Gibraltar. It has two opposing entrances connected by a channel (Fig. 1) which increases water renewal across the harbour. As a result, moderate oxygen levels are maintained in the water column and sediment heterogeneity is increased (Guerra-García 2001). Consequently, this area is a suitable site for analysing the relationships between macrofaunal assemblages and sediment variables, for elucidating the main factors affecting the spatial distribution of the soft-bottom fauna, and for evaluating possible positive effects of an increased water renewal on macrofaunal communities in harbours. Previous studies (Guerra-García and García-Gómez 2004a, 2004b) have dealt with the crustaceans and molluscs of Ceuta harbour. The present paper focuses on its polychaete assemblages.

Polychaetes are among the most frequent and abundant metazoans in marine benthic environments (Fauchald and Jumars 1979). They are widely distributed geographically and occupy a variety of marine and estuarine habitat types (Belan 2003). Polychaetes often comprise over one third of the total number of macrobenthic species (Fauchald and Jumars 1979). In marine sediments they show high species richness and diversity as well as high biomass and density, up to $80 \%$ of the total benthos abundance (Belan 2003). Polychaetes have been found to be useful indicators of organic pollution, and many species have a high level of tolerance to adverse effects such as pollution and natural perturbations (Levin et al. 1996; Borja et al. 2000; Inglis and Kross 2000; Samuelson 2001). While polychaete communities associated with macrophytes have rarely been studied with respect to environmental vari- 
ables (Sánchez-Moyano et al. 2002), relevant studies of soft-bottom polychaete assemblages are abundant (Nicolaidou and Papadopoulou 1989; Lardicci et al 1993; Pardal et al. 1993; Méndez 2002; Belan 2003). Environmental factors such as water movement, dissolved oxygen, granulometry of sediment and organic matter content have been demonstrated to play an important role in the distribution of soft-bottom polychaetes (Lardicci et al. 1993; Méndez 2002).

Usually, polychaete species richness and diversity inside harbours are low because of high pollution levels and a lack of oxygen in the water column (Estacio et al. 1997; Dhainaut-Courtois et al. 2000). The presence of two opposing entrances in Ceuta harbour, increasing water renewal and sediment heterogeneity, could have strong positive effects on polychaete assemblages inside the harbour. To test this hypothesis, we have studied and compared the physico-chemical parameters of sediments and associated polychaete assemblages at stations inside and outside the harbour.

\section{Methods}

Study area

The harbour at Ceuta is located in northern Africa, Strait of Gibraltar (Fig. 1). Inside the harbour there is a high variation in sediment characteristics (Guerra-García 2001). The presence of the San Felipe Channel promotes water renewal across the middle of the harbour and, consequently, increases sediment grain size. Nevertheless, there are also more enclosed areas where water renewal is reduced, and the mud content of sediments, silting, suspended solids and organic matter in the water column are high (Guerra-García 2001; Guerra-García and García-Gómez 2001). The harbour of Ceuta is characterised by an intense shipping traffic, and frequent loading and dumping is involved in shipping operations.
There are two urban effluent outfalls originating from the city of Ceuta, but no river empties into the harbour. In contrast to some harbours in southern Spain, such as Algeciras Port (Estacio et al. 1997), there is no significant industrial activity adjacent to Ceuta harbour. Therefore, the contamination of the harbour is mainly derived from shipping activities and sewage disposal outfalls.

Sample collection

The sampling was carried out in June 1999. A total of 21 stations (15 inside and 6 outside the harbour) were chosen to encompass the broadest range of environmental conditions. The exact location of the stations was determined by the absence of rocky outcrops. Station E10, located in the San Felipe Channel, was considered as an external station. Sediments were collected with a van Veen grab of $0.05 \mathrm{~m}^{2}$. Four grab samples were collected at each station. Three of them were allocated to study the polychaete fauna $\left(0.15 \mathrm{~m}^{2}\right)$, and the fourth was used for sediment analysis.

Processing of biological samples

The sediment samples were sieved (mesh size of $0.5 \mathrm{~mm}$ ) and the retained fractions were fixed in $4 \%$ neutral formalin stained with Rose Bengal. Organisms were sorted out by eye, identified to species level if possible, and counted.

\section{Physico-chemical analysis}

Sediments from each station were mixed and stored at $-20^{\circ} \mathrm{C}$ in pre-cleaned glass jars until analysis, and then freeze-dried. Granulometry was performed according to Buchanan and Kain (1984). The percentage of sand was used as a granulometric indicator in the environmental matrix. The organic content was analysed by two methods: (1) by ashing sediment samples (three replicates of $2 \mathrm{~g}$ each) to $500^{\circ} \mathrm{C}$ for $6 \mathrm{~h}$ and re-weighing (Estacio et al. 1997); and (2) by oxidation using $\mathrm{K}_{2} \mathrm{Cr}_{2} \mathrm{O}_{7}$ (Loring and Rantala 1977).

To estimate the percentage of the lipid fraction, freeze-dried and homogenised sediments from each stations (approx. $5 \mathrm{~g}$ ) were extracted in a $500 \mathrm{ml}$ Soxhelt extractor for $24 \mathrm{~h}$ using a mixture of dichloromethane/methanol $(9: 1, \mathrm{v}: \mathrm{v})$. The elemental sulphur was
Fig. 1 Location of the harbour of Ceuta, North Africa. The 21 sampling stations are indicated $(E 1-E 21)$

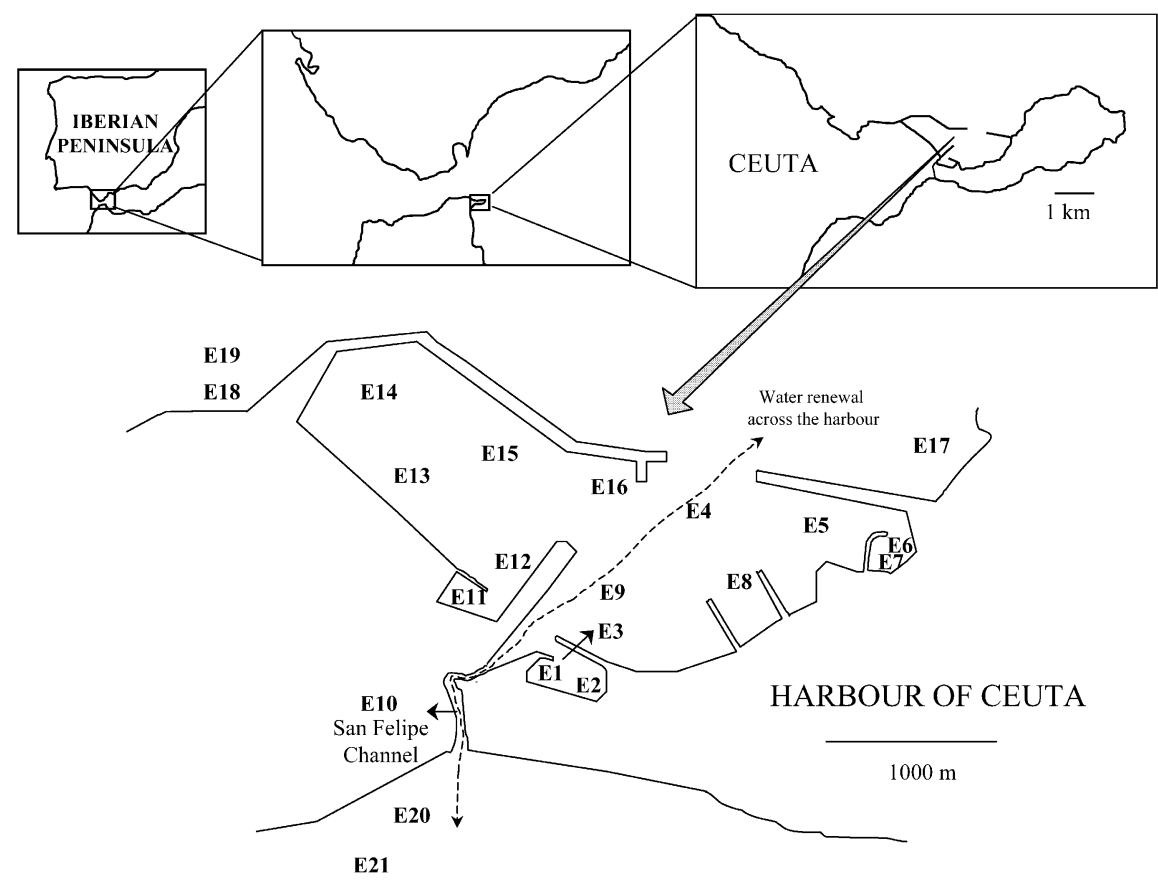


removed using copper powder (Hostettler and Kvenvolden 1994). The extracts were reduced in volume on a rotary evaporator and concentrated by gentle nitrogen "blow down". The lipid fraction was determined by gravimetry and expressed as a percentage. The total nitrogen (ppm) was assessed via Kjeldahl digestion. The concentrations of $\mathrm{P}, \mathrm{Al}, \mathrm{As}, \mathrm{B}, \mathrm{Ba}, \mathrm{Ca}, \mathrm{Cd}, \mathrm{Co}, \mathrm{Cr}, \mathrm{Cu}, \mathrm{Fe}, \mathrm{K}, \mathrm{Li}$, $\mathrm{Mg}, \mathrm{Mn}, \mathrm{Na}, \mathrm{Ni}, \mathrm{Pb}, \mathrm{S}, \mathrm{Sr}$ and $\mathrm{Zn}$ were measured using inductively coupled phasma spectrometry ICP-OES (Therme Jarrel Ash, IRIS Advantage) after digestion with aqua regia $\left(\mathrm{HNO}_{3}: \mathrm{HCl} ; 1: 3, \mathrm{v}: \mathrm{v}\right)$ in teflon-lined, high pressure decomposition vessels.

\section{Statistical analysis}

The total number of species, the Shannon-Wiener diversity index (Shannon and Weaver 1963) and Pielou's evenness index (Pielou 1966) were calculated for each station. Possible differences between internal and external stations were tested using one-way ANOVA, after verifying normality (Kolmogorov-Smirnov test) and homogeneity of variances (Barlett test). A standard productmoment correlation analysis was conducted to reduce the number of variables considered. The Principal Component Analysis was used for the ordination of stations based on the physico-chemical data. Environmental data were log $(x+1)$ transformed (Estacio et al. 1997; Guerra-García and García-Gómez 2001). The affinities among stations based on polychaete species were established by MDS (non-metric multidimensional scaling) and cluster analysis using UPGMA (unweighted pair-group method using arithmetic averages). To test the ordination, the stress coefficient of Kruskal was employed (Kruskal and Wish 1978). The relationships among environmental measures and polychaete assemblages were studied by a canonical correspondence analysis (CCA). The abundance data of polychaetes were transformed by the fourth root, and the Bray-Curtis similarity index was used (Sánchez-Moyano and García-Gómez 1998). Relationships between multivariate biological structure and environmental variables were also examined using the BIO-ENV procedure (Clarke and Ainsworth 1993). Percentage of similarity analysis (SIMPER) (Clarke 1993) was used to determine the species involved in grouping of the different stations. Multivariate analyses were carried out using the PRIMER package (Clarke and Gorley 2001) and the PC-ORD programme (McCune and Mefford 1997). For univariate analyses, the BMDP was used (Dixon 1983).

\section{Results}

Environmental variables

The standard product-moment correlation analysis of environmental data was useful to reduce the 27 variables measured (Table 1) to 11 variables. The \%lipids, B, Ba, $\mathrm{K}, \mathrm{Na}, \mathrm{S}$ and $\mathrm{OMc}$ (organic matter: calcination method) showed a strong correlation $(r>0.85, P<0.001)$ with the OMo (organic matter: oxidation method). $\mathrm{Cu}$ correlated $(r>0.85, P<0.001)$ with $\mathrm{Zn}, \mathrm{Pb}$ and As. $\mathrm{Cr}$ correlated $(r>0.9, P<0.001)$ with $\mathrm{Co}, \mathrm{Mg}$ and Ni. The correlation between $\mathrm{Al}$ and $\mathrm{Li}$ was significant $(r>0.9, P<0.001)$, and $\mathrm{Ca}$ and $\mathrm{Sr}$ were also correlated $(r>0.89, P<0.001)$. Therefore, the reduced matrix included the depth, $\%$ sand, $\mathrm{OMo}, \mathrm{N}, \mathrm{P}, \mathrm{Al}, \mathrm{Ca}, \mathrm{Cr}, \mathrm{Cu}, \mathrm{Fe}$ and $\mathrm{Mn}$.

The first axis of the PCA ordination (Fig. 2) explained $54.03 \%$ of the total variance and correlated positively with the percentage of sands, and negatively with the organic matter and the concentrations of $\mathrm{P}, \mathrm{N}, \mathrm{Al}, \mathrm{Cr}, \mathrm{Cu}$ and $\mathrm{Mn}$. The second axis, which explained $15.2 \%$, was negatively correlated with depth and $\mathrm{Ca}$. Consequently,

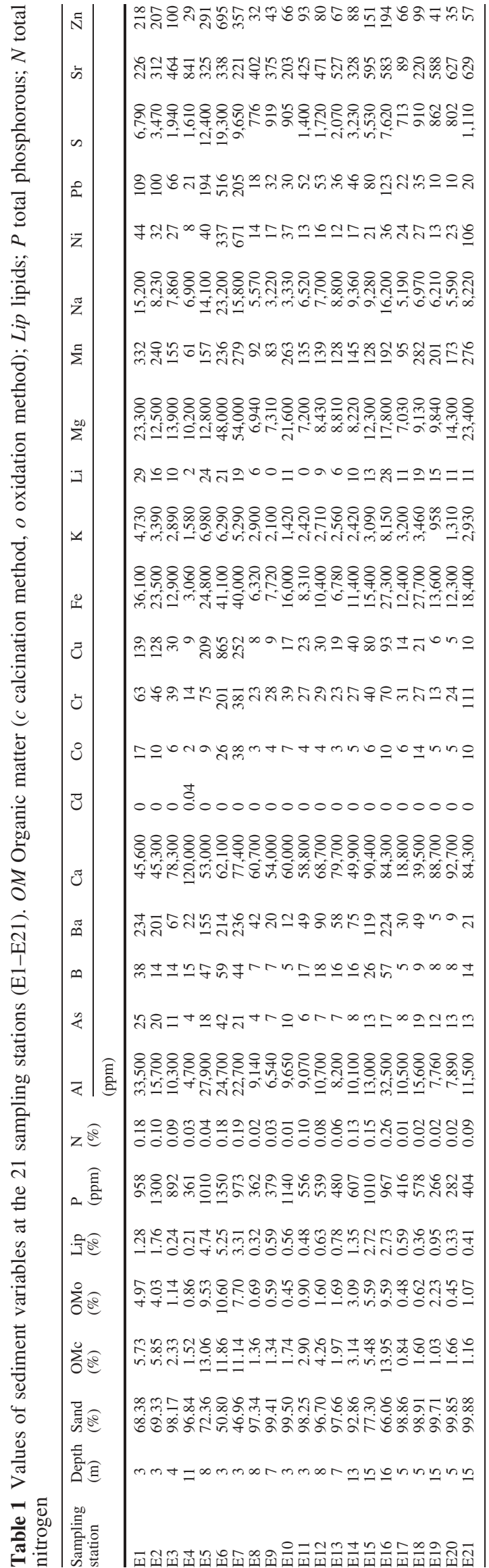




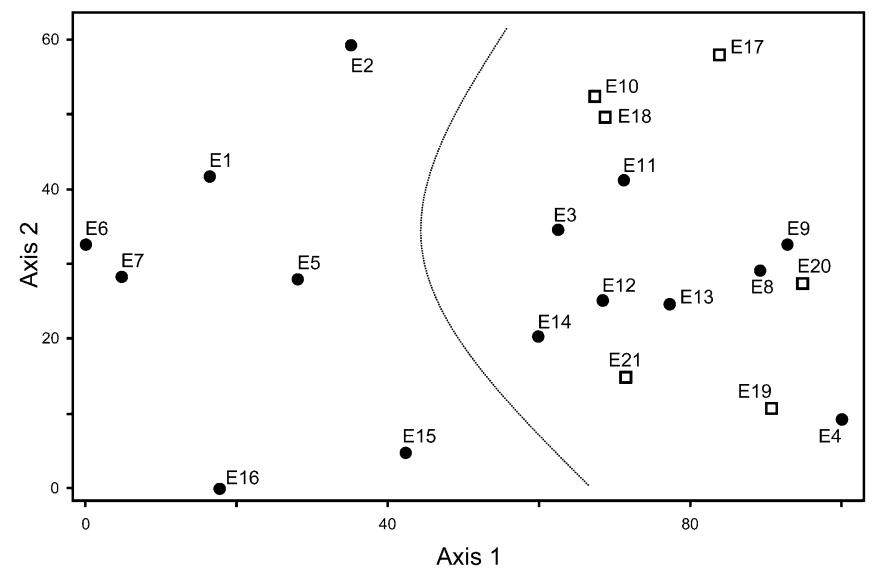

Fig. 2 PCA analysis of the physico-chemical variables measured in the sediment of each station. Circles Internal stations, squares external stations

the first axis ordinates the stations along a pollution gradient which is correlated with the type of sediment (the higher levels of pollutants in sediments were associated with lower sand content and, consequently, higher silt and clay content). The stations outside the harbour were located together with the inner stations affected by the water renewal across the San Felipe Channel in the PCA output, all characterised by high sand content, whereas stations E1, E2, E5, E6, E7, E15 and E16 were characterised by finer sediments with higher organic matter and heavy metal content. The second axis ordinates the stations mainly according to a depth gradient.

\section{Polychaete fauna}

The 21 stations provided a total of 56 species. Table 2 shows the total abundance (ind $/ 0.15 \mathrm{~m}^{2}$, sum of the three van Veen replicates) of each species at each different station. Many of the species were rare and occurred only at one or two stations. The most abundant species, Capitella capitata, Cirriformia tentaculata, Exogone verugera, Nereis falsa, Potamilla reniformis and Pseudomalacoceros tridentata, were mainly found at internal stations. The species richness and Shannon-Wiener diversity did not differ significantly between internal and external stations (Table 3), while the evenness index was slightly higher at the external stations, due to lower polychaete abundances (Fig. 3). The highest number of species were recorded at stations E4, E10 (channel) and E14 (inside the harbour), the highest diversity values at stations E4 and E9 (inside), and the highest evenness values at stations E17 and E18 (outside). It is remarkable that even the stations with extremely high levels of organic matter (particularly lipids) and heavy metals, such as the internal stations E5, E6, E7 and E16, are characterised by similar values of species richness and similar diversity indexes as the unpolluted external stations (Table 1, Fig. 3).

When the multivariate approach was used, the external stations were clearly separated from the internal stations
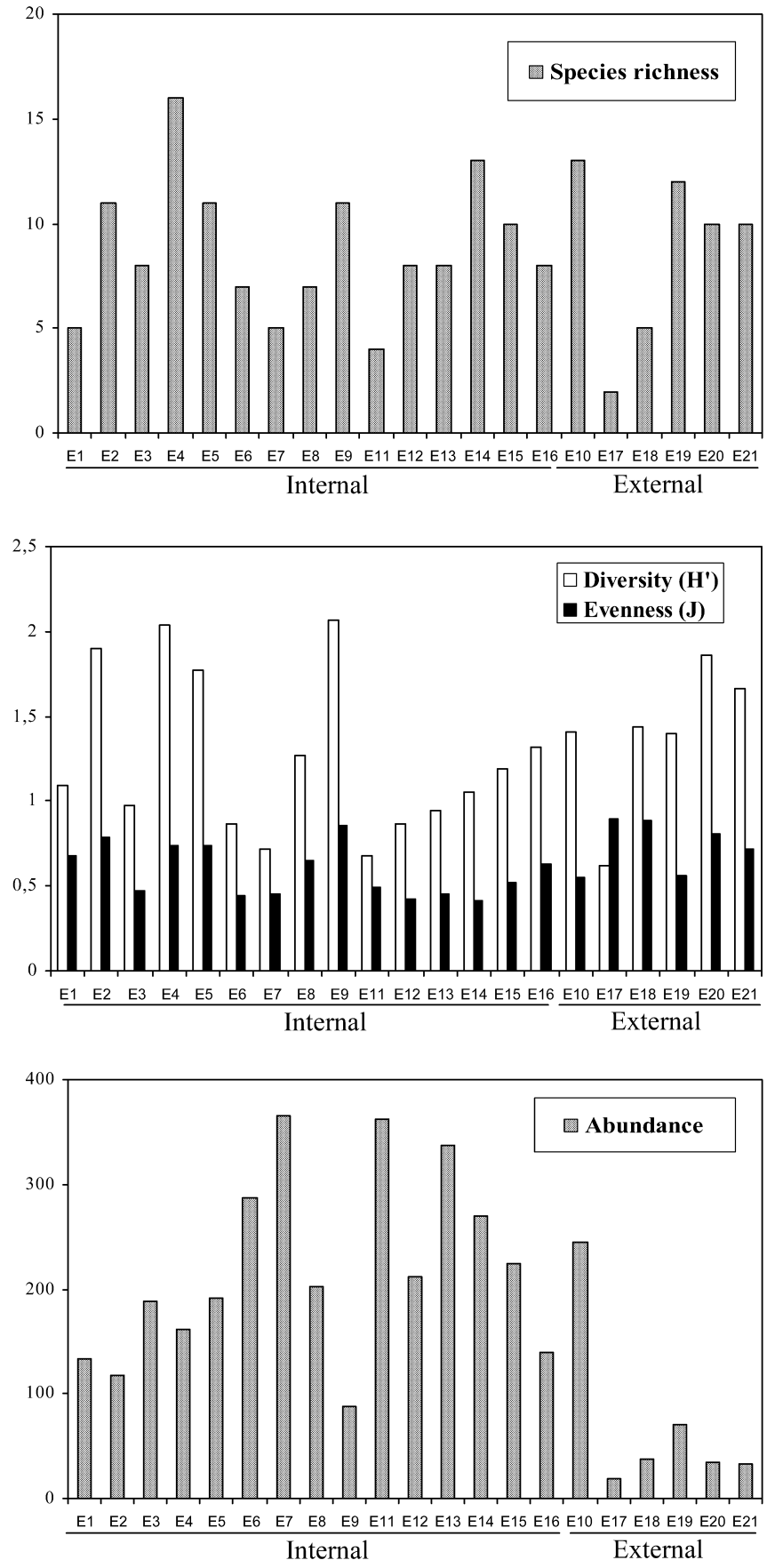

Fig. 3 Species richness, Shannon-Wiener diversity index $\left(H^{\prime}\right)$, Pielou Evenness index $(J)$ and abundance $\left(\right.$ ind $\left./ 0.15 \mathrm{~m}^{2}\right)$ at the 21 sampling stations

(Fig. 4). This indicates that, although species richness and diversity values are similar inside and outside the harbour, the species composition allows for a discrimination between internal and external stations, even better than environmental parameters (Fig. 2). The external stations E10 (Channel) and E17 (San Amaro) are also separated from the rest of the external stations.

Table 4 shows the average abundance of the most relevant species, listed in order of decreasing contribution 
Table 2 Total abundance (ind/ $0.15 \mathrm{~m}^{2}$, sum of the three van Veen replicates) of each species at each different station

Ammotrypane aulogaster Rathke, 1843

Amphiglena mediterranea (Leydig, 1851)

Anaitides maderiensis (Langerhans, 1880)

Aonides oxycephala (Sars, 1862)

Aricidea jeffreysii (McIntosh, 1879)

Branchiomma bombyx (Dalyell, 1853)

Capitella capitata (Fabricius, 1780)

Chloeia venusta Quatrefages, 1865

Chone collaris (Langerhans, 1880)

Chone sp

Cirratulus cirratus (Muller, 1776)

Cirriformia tentaculata (Montagu, 1808)

Ehlersia ferrugina Langerhans, 1881

Euclymene collaris (Claparede, 1870)

Euclymene lumbricoides (Quatrefages, 1865)

Euphrosyne foliosa Audouin and Milne-Edwards, 1833

Exogone verugera Claparede, 1868

Glycera capitata Oersted, 1843

Harmotoe imbricata (Linnaeus, 1767)

Hyalinoecia bilineata Baird, 1870

Jasmineira elegans Joseph, 1894

Lagis koreni Malmgren, 1866

Lumbrinereis latreilli Audouin and Milne-Edwards, 1834 Lumbrinereis sp

Marphysa belli (Audouin and Milne-Edwards, 1833)

Neanthes caudata (Delle Chiaje, 1828)

Nephthys cirrosa Ehlers, 1868

Nereis falsa Quatrefages, 1865

Notomastus latericius Sars, 1851

Oriopsis eimeri (Langerhans, 1880)

Owenia fusiformis Delle Chiaje, 1844

Paradoneis lyra (Southern, 1914)

Parapionosyllis labronica Cognetti, 1965

Pherusa eruca (Clapavede, 1870)

Platynereis dumerilii Audouin and Milne-Edwards, 1833

Potamilla reniformis (Linnaeus, 1788)

Protoaericia oerstedii (Claparade, 1864)

Pseudomalacoceros tridentata (Southern, 1914)

Pseudopolydora antennata (Claparede, 1868)

Schistomeringos neglecta (Fauvel, 1923)

Scolelepis fuliginosa (Claparede, 1870)

Scolelepis squamata (Muller, 1806)

Scoloplos armiger (Müller, 1776)

Sigambra tentaculata (Treadwell, 1941)

Sphaerodoropsis minutum (Webster and Benedict, 1887) Sphaerodorum gracile (Rathke, 1843)

Sphaerosyllis hystrix Claparede, 1863

Sphaerosyllis pirifera Claparede, 1868

Streblosoma bairdi (Malmgren, 1866)

Subadyte pellucida (Ehlers, 1864)

Syllidea armata Quatrefages, 1865

Syllis beneliahuae (Campoy and Alquezar, 1982)

Syllis garciai (Campoy, 1982)

Syllis gracilis Grube, 1840

Syllis krohni Ehlers, 1864

Syllis rosea (Langerhans, 1879)

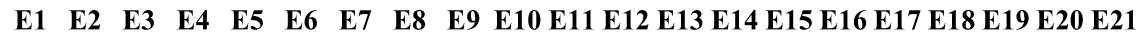

\begin{tabular}{|c|c|c|c|c|c|c|c|c|c|c|c|c|}
\hline & & & & & & & & & & & & \\
\hline & & & & & & & & & & & & \\
\hline & & & & & & & & & & ( & & \\
\hline & & & & & & & & & & & & \\
\hline & & & & & & & & & & & & \\
\hline & & & & & & & & & & & & \\
\hline & & & & & & & & & & 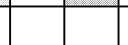 & & \\
\hline & & & & & & & & 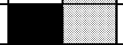 & $=$ & | & & \\
\hline & & & & & & & & & \begin{tabular}{l|l} 
& \\
\end{tabular} & \begin{tabular}{|l|l|} 
& \\
\end{tabular} & & \\
\hline & & & & & & & & & & & & \\
\hline & & & & & & & & & & & & \\
\hline & & & & & & & & & \begin{tabular}{|l|l|} 
& \\
\end{tabular} & \begin{tabular}{l|l|l|} 
& \\
\end{tabular} & & \\
\hline & & & & & & & & & & & & \\
\hline & & & & & & & & & \begin{tabular}{|l|l|}
+2 \\
\end{tabular} & \begin{tabular}{|l|l|} 
& \\
\end{tabular} & & \\
\hline & & & & & & & & & & \begin{tabular}{l|l|} 
& \\
\end{tabular} & & \\
\hline & & & & & & & & & & & & \\
\hline & & & & & & & & & & & & \\
\hline & & & & & & & & & & & & \\
\hline & & & & & & & & & & \begin{tabular}{l|l|l|}
+1 &
\end{tabular} & & \\
\hline & & & & & & & & & & \begin{tabular}{|l|} 
\\
\end{tabular} & & \\
\hline & & & & & & & & & & & & \\
\hline & & & & & & & & & & 2 & & \\
\hline & & & & & & & & & \begin{tabular}{|l|l|} 
& \\
\end{tabular} & 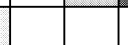 & & \\
\hline & & & & & & & & & & 7 & & \\
\hline & & & & & & & & & & 4 & & \\
\hline & & & & & & & & & & & & \\
\hline & & & & & & & & & & & & \\
\hline & & & & & & & & 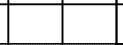 & \begin{tabular}{|l|l|} 
& \\
\end{tabular} & \begin{tabular}{l|l|l|} 
&
\end{tabular} & & \\
\hline & & & & & & & & & & & & \\
\hline & & & & & & & & & & & & \\
\hline & & & & & & & & & & & & \\
\hline & & & & & & & & & & & & \\
\hline & & & & & & & & & & 1 & & \\
\hline & & & & & & & & & & & & \\
\hline & & & & & & & & & & & & \\
\hline & & & & & & & & & & 1 & & \\
\hline & & & & & & & & & & & & \\
\hline & & & & & & & & & 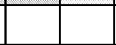 & -1 & 4 & \\
\hline & & & & & & & & & & 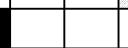 & 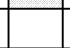 & \\
\hline & & & & & & & & & 2 & 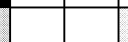 & & \\
\hline & & & & & & & & & & 1 & & \\
\hline & & & & & & & & & & & & \\
\hline & & & & & & & & & & & & \\
\hline & & & & & & & & & & & & \\
\hline & & & & & & & & & & & & \\
\hline & & & & & & & & & & & & \\
\hline & & & & & & & & & & & & \\
\hline & & & & & & & & & & & & \\
\hline & & & & & & & & & & & & \\
\hline & & & & & & & & & & & & \\
\hline & & & & & & & & & & & & \\
\hline & & & & & & & & & & & & \\
\hline & & & & & & & & & & & & \\
\hline & & & & & & & & & & & & \\
\hline & & & & & & & & & & & & \\
\hline & & & & & & & & & & & & \\
\hline & & & & & & 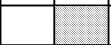 & & & 1 & 1 & 1 & \\
\hline
\end{tabular}


Table 3 Mean values, standard deviations (SD) and ranges of the number of species, diversity $\left(H^{\prime}\right)$, evenness $(J)$ per $0.15 \mathrm{~m}^{2}$ for internal $(n=15)$ versus external $(n=6)$ stations ( $n s$ not significant, $* P<0.05)$

\begin{tabular}{|c|c|c|c|c|c|}
\hline & \multicolumn{2}{|c|}{ Internal stations } & \multicolumn{2}{|c|}{ External stations } & \multirow{2}{*}{$\frac{\text { One-way ANOVA }}{F}$} \\
\hline & Mean \pm SD & Range & Mean \pm SD & Range & \\
\hline Number of species & $8.93 \pm 3.49$ & $4-16$ & $8.83 \pm 4.49$ & $2-13$ & 0.88 n.s. \\
\hline Diversity $\left(H^{\prime}\right)$ & $1.25 \pm 0.47$ & $0.72-2.07$ & $1.40 \pm 0.41$ & $0.62-1.86$ & 0.43 n.s. \\
\hline Evenness $(J)$ & $0.58 \pm 0.15$ & $0.41-0.86$ & $0.74 \pm 0.15$ & $0.55-0.90$ & $4.53^{*}$ \\
\hline
\end{tabular}
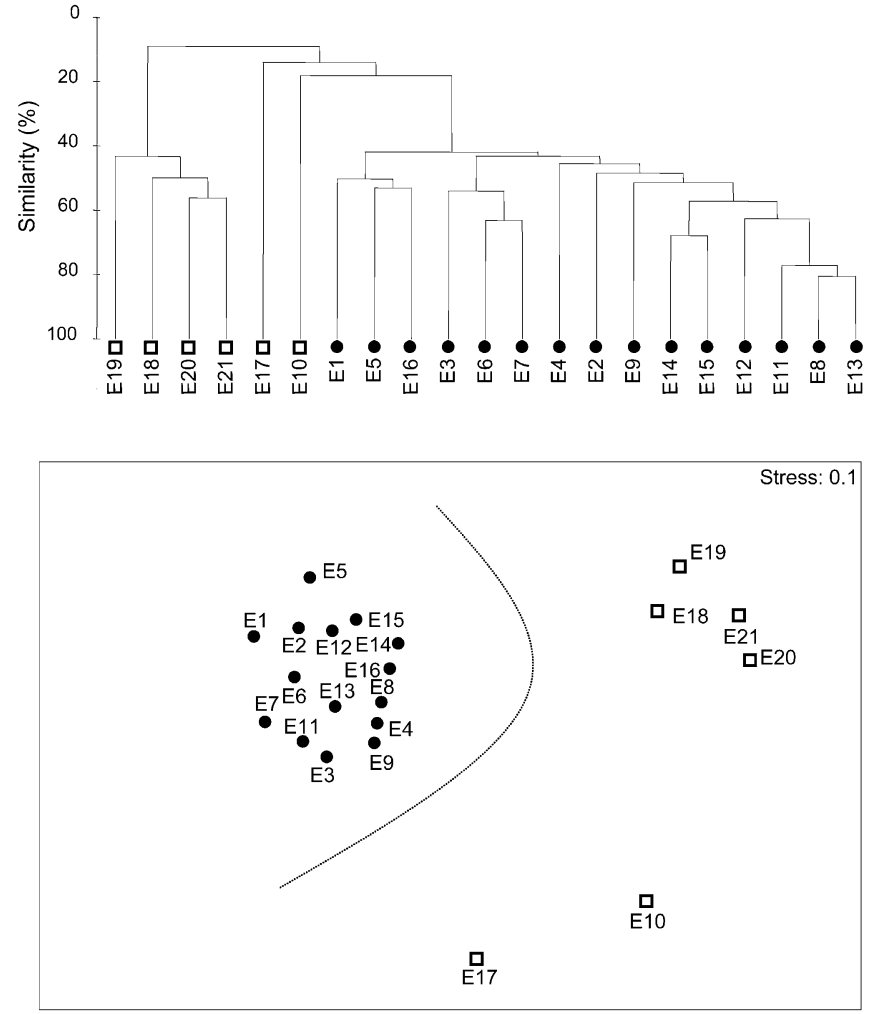

Fig. 4 Cluster classification and MDS ordination of the stations according to the abundance of polychaete species. Inner and outer stations are separated by doted line. Circles Internal stations, squares external stations to the average dissimilarity. The spionid Pseudomalacoceros tridentata was the species which contributed most to the dissimilarity between internal/external stations. It was present or abundant at all internal stations, but absent from all external stations. Capitella capitata, Potamilla reniformis and Nereis falsa followed the same general pattern, although they were present at some external stations. Cirriformia tentaculata and Platynereis dumerilii were not found outside the harbour. On the other hand, Jasmineira elegans, Parapionosyllis labronia, Glycera capitata and Anaitides maderiensis were only found outside the harbour. Hyalinoecia bilineata was abundant at station E10 (San Felipe Channel) and was also present at stations E4 and E9, which are affected by the water renewal across the harbour.

Polychaete assemblages and environmental measures

The canonical correspondence analysis (CCA) confirmed the ordination of the stations previously obtained by the Cluster and MDS analysis. The external stations are distributed along the positive part of axis 1 (Fig. 5). Axis 1 seems to separate the stations according to a pollution gradient mainly determined by phosphorous and heavy metals such as $\mathrm{Cu}$ (and consequently $\mathrm{Zn}, \mathrm{Pb}$ and $\mathrm{As}$, highly correlated with $\mathrm{Cu}$ ). Species such as Jasmineira elegans, Parapionosyllis labronica, Glycera capitata, Schistomeringos neglecta and Anaitides maderiensis, distributed in the external stations, are located at the positive end of axis 1, while Pseudomalacoceros tirdentata, Potamilla reniformis, Capitella capitata and Platynereis dumerilii are grouped at the negative end of axis 1, as-
Table 4 Average abundances of the most relevant species of the stations located at the internal (INT) and external (EXT) sites. Species are listed in order of decreasing contribution to the average dissimilarity $(A v$. $D i s$.) between the two groups up to about $70 \%$ of accumulated total dissimilarity (Cum. Dis.\%). The ratio indicates Dis./SD. The total average dissimilarity between groups is $88.02 \%$

\begin{tabular}{lrrrrrr}
\hline Species & $\begin{array}{c}\text { Abund. } \\
\text { INT. }\end{array}$ & $\begin{array}{l}\text { Abund. } \\
\text { EXT. }\end{array}$ & Av. Dis. & Ratio & Dis.\% & Cum. Dis.\% \\
\hline Pseudomalacoceros tridentata & 120.07 & 0.00 & 12.31 & 2.73 & 13.98 & 13.98 \\
Capitella capitata & 42.87 & 2.33 & 6.16 & 1.22 & 6.99 & 20.98 \\
Jasmineira elegans & 0.00 & 14.00 & 5.07 & 1.36 & 5.76 & 26.73 \\
Potamilla reniformis & 8.87 & 0.50 & 4.60 & 1.44 & 5.23 & 31.96 \\
Nereis falsa & 6.20 & 2.17 & 4.03 & 1.34 & 4.58 & 36.55 \\
Cirriformia tentaculata & 7.47 & 0.00 & 3.77 & 0.97 & 4.28 & 40.83 \\
Exogone verugera & 5.53 & 3.83 & 3.71 & 1.02 & 4.22 & 45.05 \\
Parapionosyllis labronica & 0.00 & 3.33 & 3.61 & 1.29 & 4.10 & 49.14 \\
Aricidea jeffreysii & 2.53 & 2.33 & 3.05 & 1.03 & 3.46 & 52.60 \\
Ehlersia ferruginea & 3.93 & 0.67 & 2.77 & 1.00 & 3.15 & 55.76 \\
Glycera capitata & 0.00 & 1.00 & 2.72 & 1.36 & 3.10 & 58.85 \\
Pseudopolydora antennata & 1.13 & 0.83 & 2.21 & 0.87 & 2.51 & 61.36 \\
Hyalinoecia bilineata & 1.27 & 24.50 & 2.16 & 0.58 & 2.46 & 63.82 \\
Platynereis dumerilii & 5.00 & 0.00 & 2.08 & 0.55 & 2.37 & 66.19 \\
Anaitides maderiensis & 0.00 & 1.33 & 2.03 & 0.98 & 2.31 & 68.49 \\
Schistomeringos neglecta & 0.00 & 0.50 & 1.69 & 0.96 & 1.92 & 70.41 \\
\hline
\end{tabular}




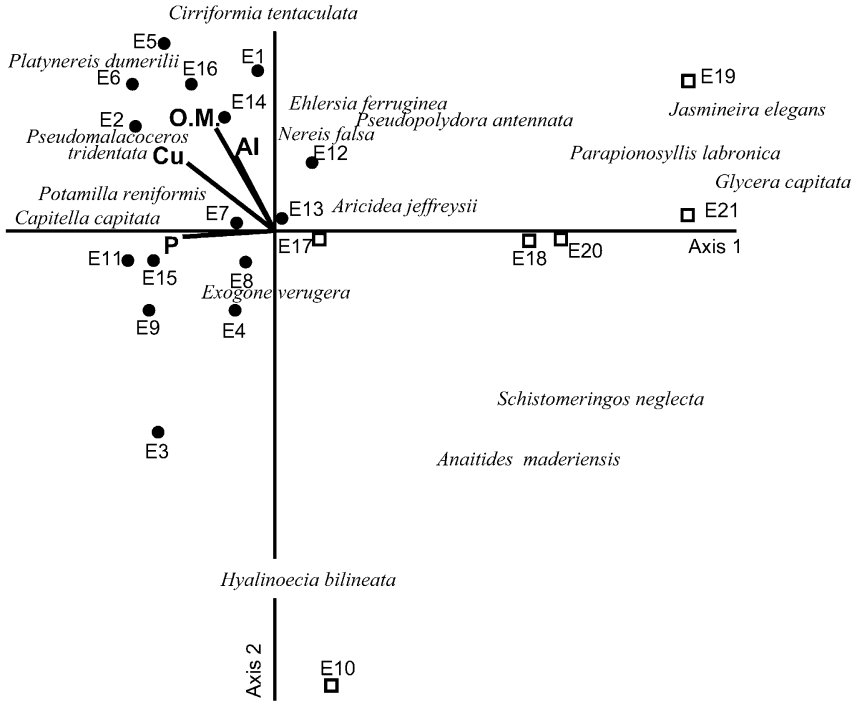

Fig. 5 Graph representation of the canonical correspondence analysis (CCA). The species included are those which contributed most to the dissimilarity between internal and external stations according to the SIMPER (Table 4). Circles Internal stations, squares external stations

sociated with the highest concentrations of $\mathrm{P}, \mathrm{Cu}$ and organic matter in the sediment. Axis 2 is mainly correlated with the organic matter. This axis separates station E10 from the remaining stations based on the presence of Hyalinoecia bilineata. According to the BIO-ENV, the best combination of variables to explain the biological data $(r=0.42)$ was obtained from the combination of five variables from the reduced matrix $(\mathrm{Cu}, \mathrm{P}, \mathrm{Ca}, \mathrm{Mn}$, \%sand).

\section{Discussion}

Since harbours are protected waterways, often with limited water circulation and surrounded by urban and industrial activities, pollutants frequently accumulate on the bottom over time (Reish and Gerlinger 1997). Ceuta harbour is considerably polluted, but provided with a channel which increases the water renewal inside the harbour (Guerra-García 2001). Due to this channel, the polychaete species richness inside Ceuta harbour is unusually high compared with harbours in southern Spain, such as Saladillo harbour, studied by Estacio (1996) and Estacio et al. (1997). This harbour, located in Algeciras Bay, shows similar levels of sediment pollution to Ceuta harbour. However, it has only one entrance and the macrofaunal communities are very poor inside this harbour. Even polychaete species, traditionally considered to be more resistant to pollution than crustaceans and molluscs, occur at considerably lower numbers in Saladillo harbour than in Ceuta harbour.

The positive effect of the channel is particularly evident for some species, such as Hyalinoecia bilineata which was found in high densities at station E10 (Channel) and sta- tions E9 and E4, which are located in the area affected more by the water renewal through the channel. Although the channel mainly affects the central area of the harbour, it is remarkable that even the most enclosed areas are characterised by moderately high values of species richness and diversity. These values are considerably higher than in other harbours, in which the most enclosed areas are characterised by a complete absence of species (Dhainaut-Courtois et al. 2000; Méndez 2002).

In the present study, the univariate analysis was not able to discriminate clearly between internal and external stations, since species richness and diversity values were rather similar inside and outside the harbour. Only the evenness index was significantly higher outside the harbour due to the lower abundances at the external stations. Usually, the outer zones of harbours or bays are characterised by a higher number of species with few individuals (Sánchez-Moyano et al. 2002). The multivariate analysis based on species composition discriminated between internal and external stations much better than the univariate approach. Consequently, the species composition and species abundance differ between inner and outer sites. The presence of the channel seems to contribute to a high species richness in polluted sediments, and the type of pollution seems to determine which species can inhabit the area. The different composition of species inside versus outside the harbour, shown by the Cluster and MDS analysis, was also supported by the SIMPER. Under Ceuta harbour conditions (polluted sediments but high water renewal), the polychaete community, rather than crustaceans and molluscs (Guerra-García 2001), is a useful bioindicator to discriminate between internal and external stations.

In general, the soft-bottom polychaete fauna has proved to be an important tool for characterising the system with respect to granulometry, salinity, and organic matter content of sediments (Raman and Ganapati 1983; Pardal et al. 1993; Méndez 2002). Other authors, however, have pointed out that water depth is the factor which best explains polychaete distribution (Nicolaidou and Papadopoulou 1989). On the other hand, Lardicci et al. (1993) and Mistri et al. (2002) found that water movement and dissolved oxygen in the water column were the main factors determining polychaete assemblages, being more important than sediment grain size, salinity, etc. These results are in agreement with those of the present study, which has demonstrated that increased water renewal promotes the establishment of well-structured diverse polychaete communities.

The present study revealed that the observed distribution of polychaetes is not determined by one of the measured sediment variables per se, but by a combination of variables. Taking into account that internal and external stations can be distinguished better by polychaete assemblages (Fig. 4) than by physico-chemical parameters (Fig. 2), there may be further variables not analysed in the present study which could influence species distribution. For example, recent studies have shown that the proportion of maltenes and asphaltenes in the hydro- 
carbon fraction of the sediments, not usually measured, might be an important factor affecting macrofaunal assemblages (Guerra-García et al. 2003a).

The polychaete communities of soft-bottom sites seem to be a better bioindicator of environmental gradients than those associated with macrophytes. Recently, SánchezMoyano et al. (2002) studied the effect of environmental factors on the spatial variation of epifaunal polychaetes on the alga Halopteris scoparia in Algeciras Bay, Strait of Gibraltar, and found little variation.

Pseudomalacoceros tridentata and Capitella capitata were the dominant polychaetes inside the harbour. Capitella capitata is considered to be one of the global opportunistic species in disturbed marine sediments rich in organic matter (Grassle and Grassle 1974; Pearson and Rosenberg 1978; Grall and Glémarec 1997; Newell et al. 1998). The spionid Pseudomalacoceros tridentata has a great capacity for recolonising disturbed soft-bottom areas and can be found in dense aggregations inside harbour facilities (Guerra-García et al. 2003b). Jasmineira elegans, Parapionosyllis labronica and Glycera capitata were the most "sensitive" species and were found only at the external stations. Glycera capitata has been reported in outer areas of other harbours, while being absent from internal stations (Belan 2003).

\section{Environmental implications of two-entrances harbours}

Conventional harbours usually only have one entrance, and when they have two entrances, both are located at the same side (Yin et al. 2000). The existence of two opposing entrances and a connecting channel in Ceuta harbour contributes to increased water movement across the harbour, allowing the establishment of diverse polychaete communities even in heavily polluted sediments. These findings should be taken into consideration for future design, construction and remodelling of harbours.

Acknowledgements We are very grateful to Compañía del Mar and Club Calypso for assistance during the sampling. Thanks are also due to our colleague S. Moreno for collaborating in the sample collection, and to E. García-Adiego for helping with the polychaete identification. We express our gratitude to Asamblea de Ceuta and to the Ministry of Education, Culture and Sport of Spain (grant FPU AP98/28617065) for financial support.

\section{References}

Belan TA (2003) Marine environmental quality assessment using polychaete taxocene characteristics in Vancouver harbour. Mar Environ Res 57:89-101

Borja A, Franco J, Pérez V (2000) A marine biotic index to establish the ecological quality of soft-bottom benthos within European estuarine and coastal environments. Mar Pollut Bull 40:1100-1114

Buchanan JD, Kain JM (1984) Measurement of the physical and chemical environment. In: Holme NL, McIntyre AD (eds) Methods for the study of marine benthos. Blackwell, Oxford, pp 30-50
Clarke KR (1993) Non-parametric multivariate analyses of changes in community structure. Aust J Ecol 18:117-143

Clarke KR, Ainsworth M (1993) A method of linking multivariate community structure to environmental variables. Mar Ecol Prog Ser 92:205-219

Clarke KR, Gorley RN (2001) Primer (Plymouth Routines In Multivariate Ecological Research) v5: user manual/tutorial. PRIMER-E, Plymouth, UK

Danulat E, Muniz P, García-Alonso J, Yannicelli B (2002) First assessment of the highly contaminated harbour of Montevideo, Uruguay. Mar Pollut Bull 44:551-576

Dhainaut-Courtois N, Pruvot C, Empis A, Baudet K (2000) Les peuplements macrozoobenthiques indicateurs des qualités physico-chimiques et chimiques des sédiments portuairesexemple du Port de Boulogne-sur-mer (Manche). Bull Soc Zool Fr 125:49-62

Dixon W J (1993) BMDP statistical software. University of California Press, Berkeley

Estacio FJ (1996) Distribución y variación espacio-temporal de las comunidades macrobentónicas del sedimento en la Bahía de Algeciras. Implicaciones en la evaluación de la calidad ambiental del medio marino. Ph.D. thesis, University of Seville

Estacio FJ, García-Adiego EM, Fa DA, García-Gómez JC, Daza JL, Hortas F, Gómez-Ariza JL (1997) Ecological analysis in a polluted area of Algeciras Bay (Southern Spain): external "versus" internal outfalls and environmental implications. Mar Pollut Bull 34:780-793

Fauchald K, Jumars P (1979) The diet of worms: a study of polychaete feeding guilds. Oceanogr Mar Biol Annu Rev 16:229311

Grall J, Glémarec M (1997) Using biotic indices to estimate macrobenthic community perturbations in the Bay of Brest. Estuar Coast Shelf Sci 44:43-53

Grassle JF, Grassle P (1974) Opportunistic life histories and genetic systems in marine benthic polychaetes. J Mar Res 32:253-284

Guerra-García JM (2001) Análisis integrado de las perturbaciones antropogénicas en sedimentos del Puerto de Ceuta. Efecto sobre las comunidades macrobentónicas e implicaciones ambientales. Ph.D. thesis, University of Seville

Guerra-García JM, García-Gómez JC (2001) The spatial distribution of Caprellidea (Crustacea: Amphipoda): a stress bioindicator in Ceuta (North Africa, Gibraltar area). PSZN Mar Ecol 32:357-367

Guerra-García JM, García-Gómez JC (2004a) Crustacean assemblages and sediment pollution in an exceptional case study: a harbour with two opposing entrances. Crustaceana (in press)

Guerra-García JM, García-Gómez JC (2004b) Soft bottom mollusc assemblages and pollution in a harbour with two opposing entrances. Estuar Coast Shelf Sci 60:273-283

Guerra-García JM, González-Vila FJ, García-Gómez JC (2003a) Aliphatic hydrocarbon pollution and macrobenthic assemblages in the harbour of Ceuta. A multivariate approach. Mar Ecol Prog Ser 263:127-138

Guerra-García JM, Corzo J, García-Gómez JC (2003b) Short-term benthic recolonization after dredging in the harbour of Ceuta, North Africa. PSZN Mar Ecol 24:1-13

Hostettler FD, Kvenvolden KA (1994) Geochemical changes in crude oil spilled from the Exxon Valdez supertanker into Prince William Sound, Alaska. Org Geochem 21:927-936

Inglis GJ, Kross JE (2000) Evidence for systematic changes in the benthic fauna of tropical estuaries as a result of urbanization. Mar Pollut Bull 41:367-376

Kruskal JB, Wish M (1978) Multidimensional scaling. Sage Publications, Beverley Hills, Calif.

Lardicci C, Abbiati M, Crema R, Morri C, Bianchi CN, Castelli A (1993) The distribution of polychaetes along environmental gradients: an example from the Orbetello Lagoon, Italy. PSZN Mar Ecol 14:35-52

Levin L, Caswell H, Bridges T, DiBacco C, Cabrera D, Plaia G (1996) Demographic responses of estuarine polychaetes to pollutants: life table response experiments. Ecol Appl 6:12951313 
Loring DH, Rantala RTT (1977) Geochemical analyses of marine sediments and suspended particulate matter. Fish Mar Serv Tech Rep 700:1-44

McCune B, Mefford MJ (1997) PC-ORD. Multivariate analysis of ecological data. Mjm Software Design, Gleneden Beach

Méndez N (2002) Annelid assemblages in soft bottoms subjected to human impact in the Urías estuary (Sinaloa, Mexico). Oceanol Acta 25:139-147

Mistri M, Fano EA, Ghion F, Rossi R (2002) Disturbance and community pattern of polychaetes inhabiting Valle Magnavacca (Valli di Comacchio, Northern Adriatic Sea, Italy). PSZN Mar Ecol 23:31-49

Newell RC, Seiderer LJ, Hitchcock DR (1998) The impact of dredging works in coastal waters: a review of the sensitivity to disturbance and subsequent recovery of biological resources on the sea bed. Oceanogr Mar Biol Annu Rev 36:127-178

Nicolaidou A, Papadopoulou KN (1989) Factors affecting the distribution and diversity of polychaetes in Amvrakikos Bay, Greece. PSZN Mar Ecol 10:193-204

Pardal MA, Marques JC, Bellan G (1993) Spatial distribution and seasonal variation of subtidal polychaete populations in the Montego estuary (western Portugal). Cah Biol Mar 34:497-512

Pearson TH, Rosenberg R (1978) Macrobenthic succession in relation to organic enrichment and pollution of the marine environment. Oceanogr Mar Biol Annu Rev 16:229-311
Pielou EC (1966) The measurement of diversity in different types of biological collections. J Theor Biol 13:131-144

Raman AV, Ganapati PN (1983) Pollution effects on ecobiology of benthic polychaetes in Visakhapatnam harbour (Bay of Bengal). Mar Pollut Bull 14:46-52

Reish DJ, Gerlinger TV (1997) A review of the toxicological studies with polychaetous annelids. Bull Mar Sci 60:584-607

Samuelson GM (2001) Polychaetes as indicators of environmental disturbance on subarctic tidal flats, Iqaluit, Baffin Island, Nunavut Territory. Mar Pollut Bull 49:733-741

Sánchez-Moyano JE, García-Gómez JC (1998) The arthropod community, especially Crustacea, as a bioindicator in Algeciras Bay (Southern Spain) based on a spatial distribution. J Coast Res 14:1119-1133

Sánchez-Moyano JE, García-Adiego EM, Estacio F, García-Gómez JC (2002) Effect of environmental factors on the spatial variation of the epifaunal polychaetes of the alga Halopteris scoparia in Algeciras Bay (Strait of Gibraltar). Hydrobiologia 470:133-148

Shannon CE, Weaver W (1963) The mathematical theory of communication. University of Illinois Press, Urbana

Yin J, Falconer RA, Chen Y, Probert SD (2000) Water and sediment movements in harbours. Appl Energy 67:341-352 